E-ISSN : 2477-0124
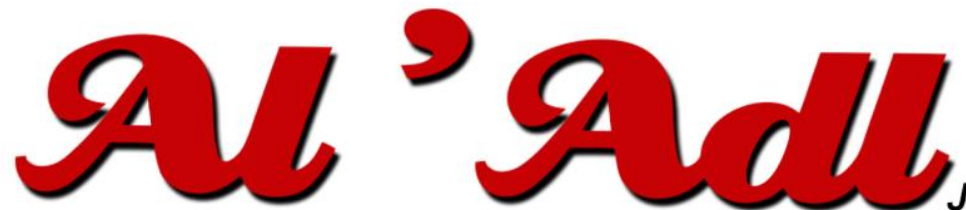

Jurnal Hukum

Editorial Office: Faculty of Law, Islamic University Of Kalimantan,

Jalan Adhyaksa No. 2 Kayutangi Banjarmasin, Kalimantan Selatan, Indonesia (70123)

Email: al_adl@uniska-bjm.ac.id

Web: http://ojs.uniska-bjm.ac.id

\section{TINJAUAN HUKUM TERHADAP EKSISTENSI UNIT USAHA SYARIAH BANK JAWA TENGAH}

\author{
Muhammad Fuad Hakim Zamzami*, Ro'fah Setyowati \\ Fakultas Hukum, Universitas Diponegoro \\ J1. Imam Bardjo, S.H. No.1-3 Kampus UNDIP Pleburan \\ Email: hakimzamzami03@gmail.com
}

$\begin{array}{ll}\text { *Corresponding author } \\ \text { Submitted } & : \text { 15 Desember } 2022 \\ \text { Revised } & : \text { 06 Januari } 2022 \\ \text { Accepted } & : \text { 22 Januari } 2022 \\ \text { Published } & : \text { 26 Januari } 2022\end{array}$

\begin{abstract}
The existence of The Islamic Business Unit of Jateng Bank is not in a good condition due to several technical and non-technical problems. As a result of the existence problems of sharia business unit, hence this research will specifically discuss the existence of Sharia Business Unit, PT. Jateng Bank and pertaining to the strategy of sharia business unit, PT. Central Java Regional Development Bank in order to more exist. The research method used was empirical juridical - using primary legal data. The results revealed that the Sharia Business Unit of Jateng Bank still experiences some obstacles that make it non-existent. There are 6 (six) strategic steps to make the Sharia Business Unit of Jateng Bank more exist. Starting from determining superior market segmentation, product and service development, integration and synergy, revitalization of internal provisions related to business dynamics, Revitalization in SDI field as a business growth driver and strengthening corporate culture, and integration of services and maximizing Sharia services on the Jateng network Bank.
\end{abstract}

Keywords: Existence; Sharia Business Unit; Central Java Bank.

\section{Abstrak}

Eksistensi Unit Usaha Syariah Bank Jateng sedang tidak baik, hal ini dikarenakan beberapa permasalahan teknis dan non teknis yang dihadapi. Berdasarkan permasalahan eksistensi Unit Usaha Syariah tersebut penelitian ini akan secara spesifik membahas mengenai eksistensi Unit Usaha Syariah PT. Bank Jateng dan mengenai strategi Unit Usaha Syariah PT. Bank Pembangunan Daerah Jawa Tengah agar semakin eksis. Metode penelitian yang digunakan adalah yuridis empiris, dengan menggunakan data hukum primer. Berdasarkan hasil penelitian diketahui bahwa Unit Usaha Syariah Bank Jateng masih mengalami beberapa hambatan yang menjadikannya tidak eksis. Ada 6 (enam) langkah strategis untuk menjadikan Unit Usaha Syariah Bank Jateng semakin eksis. Mulai dari menentukan segmentasi pasar unggulan, pengembangan produk dan layanan, integrasi dan bersinergi, revitalisasi ketentuan internal terkait dengan dinamika bisnis, Revitalisasi di bidang SDI sebagai penggerak pertumbuhan bisnis dan Penguatan Corporate Culture, serta Integrasi jasa layanan dan memaksimalkan Layanan Syariah pada jaringan Bank Jateng.

Kata kunci: Eksistensi; Unit Usaha Syariah; Bank Jateng. 
Perbankan merupakan suatu lembaga jasa keuangan yang memegang peran strategis sekaligus peran vital dalam urusan keuangan negara. Lembaga keuangan perbankan merupakan lembaga intermediasi atau lembaga penghubung antara nasabah yang memiliki kelebihan uang dan nasabah yang memerlukan uang untuk pinjaman. ${ }^{1}$ Bank menjadi semakin penting keberadaannya ketika aktivitas transaksi masyarakat semakin hari semakin meningkat. Perbankan merupakan suatu tumpuan penting dalam perwujudan kesejahteraan masyarakat Indonesia, yang mayoritas beragama islam hal ini lebih dikenal dengan istilah "muamalah-syariah al Umumiyyah", perekonomian suatu negara sangat dipengaruhi dan bergantung pada perbankan. Perbankan yang mengalami peningkatan nasabahnya karena mayoritas masyarakat Indonesia beragama islam adalah perbankan syariah.

Berlandaskan pada Undang-Undang Nomor 7 Tahun 1992 tentang Perbankan, selanjutnya diamandemen dengan Undang-Undang Nomor 10 Tahun 1998, telah lahir perbankan syariah pertama di Indonesia yaitu dengan beroperasinya secara resmi Bank Muamalat Indonesia (BMI) yang berdiri pada tahun 1992, atas dasar kondisi tersebut, mulai saat itu maka diberlakukanlah dual banking system, dimana Dual Banking System memungkinkan suatu perbankan melakukan dua kegiatan bisnis sekaligus yaitu kegiatan perbankan berbasis bunga dan kegiatan perbankan berbasis syariah. ${ }^{2}$ Bank syariah yang sudah diperkuat dengan landasan hukum yang kuat pula di Indonesia dengan diundangkannya Undang-Undang Nomor 21 Tahun 2008 tentang perbankan syariah, sejak saat itu eksistensi yuridis perbankan syariah di Indonesia semakin kuat. Berdasarkan data yang dirilis bank Indonesia, perbankan syariah mengalami peningkatan secara kualitas maupun secara kuantitas. Peningkatan yang dialami bank syariah bukan hanya dari segi kuantitas namun juga dari segi kualitas layanannya dan keamanan dan keandalan sistem di dalam pelaksanaan kegiatan perbankan syariah di Indonesia. ${ }^{3}$

Kualitas layanan bank syariah semakin membaik sejak lahirnya aturan perbankan di Indonesia, yang diikuti dengan aturan perbankan syariah di Indonesia. Tujuan diundangkannya peraturan khusus terkait penyelenggaraan perbankan syariah adalah untuk menjadi landasan hukum yang kuat dalam proses pelaksanaannya. Secara yuridis berdasarkan

\footnotetext{
${ }^{1}$ Hafas Furqani dan Muhammad Adnan Syamsul Idul Adha, 'Konversi Bank Konvensional Menjadi Bank Syariah Di Indonesia', Journal of Sharia Economics, Volume 1. Nomor 1, 2020. hlm. 39.

${ }_{2}$ Maulana Hamzah, 'Optimalisasi Peran Dual Banking System Melalui Fungsi Strategis JUB Dalam Rangka Menjaga Stabilitas Sistem Keuangan Di Indonesia', La_Riba Jurnal Ekonomi Islam, Volume 3. Nomor 2, 2009. hlm. 198

${ }^{3}$ Muhammad Syafieci Antonio, Bank Syariah: Dari Teori Ke Praktik. Jakarta: Gema Insani Press, 2017. hlm. 91 .
} 
dua aturan tersebut maka semakin memperkuat dual banking system, dan dalam pelaksanaannya suatu lembaga perbankan di Indonesia banyak sekali menerapkan dual banking system. ${ }^{4}$ Bank konvensional dan bank syariah memiliki kesamaan yaitu merupakan lembaga yang melakukan kegiatan perbankan di Indonesia, namun ada perbedaan yang mendasar di antara keduanya. Bank konvensional adalah bank yang menerapkan sistem bunga dalam menjalankan kegiatan usahanya sedangkan bank syariah adalah lembaga keuangan yang usaha pokoknya memberikan kredit dan jasa-jasa dalam lalulintas pembayaran serta peredaran uang yang pengoperasiannya disesuaikan dengan prinsip-prinsip syariat Islam. ${ }^{5}$

Perbankan syariah sebagai salah satu solusi perekonomian nasional dan penerapan sistem ekonomi syariah Islam dengan mewujudkan nilai-nilai dan ajaran Islam yang mengatur bidang ekonomi umat yang tidak terlepas dari ajaran Islam yang luas dan universal. Secara garis besar, ajaran Islam mencakup semua aspek kehidupan, baik ritual maupun sosial, dalam bidang ekonomi, makna universal bahwa syariat Islam dapat diterapkan setiap saat dan plakat, tanpa memandang relilenitas etnis "rahmat lil alamin".,6

Pasal 1 angka 7 Undang-Undang Nomor 21 Tahun 2008 tentang Perbankan Syariah memberikan pengertian bahwa bank syariah merupakan bank yang menjalankan kegiatan usahanya berdasarkan prinsip syariah. Pengertian bank syariah yang tercantum dalam Undang-undang Perbankan Syariah dimaksudkan bahwa bank syariah dalam menjalankan kegiatan usahanya harus memenuhi ketentuan prinsip-prinsip syariah. Islam telah lama mengatur Hukum Muamalat, tetapi nampaknya aturan ini tidak terlalu mengakar dalam kehidupan umat Islam di Indonesia. Yang terjadi, bahwa perkembangan penerapan Hukum Muamalat dalam praktek kegiatan perbankan syariah khususnya, ternyata tidak diikuti oleh peraturan perundang-undangan yang berlaku. Berlakunya ketentuan Hukum Muamalat ini hanya bergantung pada fatwa DSN MUI (Dewan Syariah Nasional Majelis Ulama Indonesia). DSN merupakan kepanjangan dari Dewan Syariah Nasional, adalah suatu lembaga Profesional hukum Islam yang ada (ahli Fuq) seperti ekonom dan praktisi, khususnya sektor pertemuan jejaring, seperti bank, dapat melakukan tugas-tugas MUI dengan merangsang dan “menambang”. Menurut Keputusan Dewan Syari'ah Nasional Nomor 01 Tahun 2000 Majelis Ulama Indonesia (DSN-MUI) Nomor 01 Tahun 2000, misi DSN adalah mensosialisasikan

\footnotetext{
${ }^{4}$ Rachmadi Usman, Aspek Hukum Perbankan Syariah Di Indonesia. Jakarata: Sinar Grafika, 2012. hlm. 52.

${ }^{5}$ Prima Intan Sari, 'Konversi Bank Konvensional Menjadi Bank Syariah Ditinjau Dari Hukum Positif Dan Hukum Islam', At-Tasyri, Volume 11. Nomor 2, 2018. hlm. 92.

${ }^{6}$ Rof'ah Setyowati, 'Rasionalitas Pendekatan Sharia Compliance Dalam Meningkatkan Kepercayaan Nasabah Perbankan Syariah', Jurnal Hukum Ekonomi Islam, Volume 1.Nomor 1, 2017. hlm. 13.
} 
nilai-nilai syariat di bidang ekonomi. kegiatan pada umumnya dan keuangan pada khususnya, dan pengawasan daerah subtropis. Mengawasi dan melengkapi produk turunan syariah serta mengawasi implementasinya, dan sampai saat ini jumlah fatwa DSN MUI telah mencapai 61 (enam puluh satu) fatwa perihal lembaga keuangan syariah bahkan sebagian diantaranya sudah dibakukan Bank Indonesia melalui Peraturan Bank Indonesia (PBI).

Bank Jateng memiliki sejarah yang panjang sejak jaman penjajahan Belanda dan berkembang hingga saat ini memiliki salah satu Unit Usaha, yaitu Unit Usaha Bank Jateng Syariah. Unit Usaha Bank Jateng Syariah adalah Produk Perbankan Syariah Kontrak untuk Layanan dan Tata Kelola Keuangan Pemerintah Syariah. Unit Usaha Syariah (UUS) dengan izin dari Bank Indonesia Semarang No. 9/71/DS/Sm tanggal 19 November 2007. Bank Jateng diresmikan pada tanggal 26 April 2008 dan berkantor pusat di Semarang, Gedung Grinata Lantai 4 J. Pemuda No. 142 Semarang.

Unit usaha Bank Jateng yang sah memiliki maksud dan tujuan yang hampir sama dengan bank syariah lainnya, yaitu menghimpun dana dari masyarakat dan menyalurkan dana kepada masyarakat, dalam bentuk tabungan, berjangka, giro dan investasi, sekaligus menyalurkan dana melalui iB Griya, iB Multiguna dan iB Modal. Wurk, Investasi iB, KJKS iB, BPRS Wurkkapitaal iB, iB Rahn Emas. Salah satu dana yang ada di unit usaha syariah Bank Jateng saat ini adalah iB Multiguna. iB Multiguna adalah pembiayaan dengan akad murabahah untuk pembelian barang konsumtif seperti peralatan elektronik, perabot rumah tangga, dan kendaraan bermotor baru atau bekas yang tidak bertentangan dengan syariah. Namun pada praktiknya Unit Usaha Syariah Bank Jateng belum berjalan baik, hal ini terbukti karena masih minimnya jumlah nasabah Unit Usaha Syariah Bank Jateng hingga penelitian ini dilakukan. Berdasarkan uraian tersebut terlihat adanya kesenjangan antara tujuan pembentukan Unit Usaha Syariah Bank Jateng dengan praktiknya di masyarakat yang minim nasabahnya, hal ini menjadikan tujuan Unit Usaha Syariah tersebut tidak mampu mencapai tujuannya. Berdasarkan permasalahan tersebut penelitian ini akan membahas rumusan masalah sebagai berikut.

\section{RUMUSAN MASALAH}

Berdasarkan latar belakang masalah diatas, maka dapat dirumuskan suatu rumusan masalah yang akan diteliti yaitu sebagai berikut: 
1. Bagaimana analisa hukum terhadap eksistensi Unit Usaha Syariah PT. Bank Jateng?

2. Bagaimana strategi Unit Usaha Syariah PT. Bank Pembangunan Daerah Jawa Tengah agar semakin eksis?

\section{METODE PENELITIAN}

Penelitian ini menggunakan metodologi penelitian yuridis empiris dengan melakukan penelitian langsung ke objek penelitian. Obyek Penelitian ini adalah Unit Usaha Syariah Bank Jateng. Unit Usaha Syariah Bank Jateng dipilih dengan pertimbangan sebagai salah satu lembaga jasa keuangan yang memberikan kontribusi besar pada pertumbuhan ekonomi melalui bantuan permodalan khususnya di beberapa kota di Jawa Tengah. Selain itu Unit Usaha Syariah PT Bank Pembangunan Daerah Jawa Tengah membukukan laba bersih tahun berjalan pada kuartal III/2020 senilai Rp 69,08 miliar dengan aset Rp 4,82 triliun. perolehan laba tersebut ditopang oleh pendapatan dari penyaluran dana yang senilai Rp 252,4 miliar dan bagi hasil untuk pemilik dana investasi yang senilai Rp 102,8 miliar. Data hukum yang digunakan dalam penelitian ini adalah data hukum primer yang diperoleh memalui observasi dan data hukum sekunder yang diperoleh melaui studi kepustakaan. ${ }^{7}$ Analisis data dilakukan secara deskriptif analitis, dengan menggambarkan obyek penelitian, guna menjawab permasalahan penelitian.

\section{PEMBAHASAN}

\section{Analisa Hukum Terhadap Eksistensi Unit Usaha Syariah PT. Bank Jateng}

Kehadiran Undang-Undang Nomor 21 Tahun 2008 ini didasarkan atas 3 pemikiran yaitu, pertama bahwa memaksimalkan kontribusi seluruh elemen masyarakat dalam pembangunan ekonomi nasional. Salah satunya adalah mengintegrasikan sistem ekonomi berdasarkan syariah ke dalam sistem hukum nasional. Kedua, prinsip bagi hasil yang dikembangkan oleh bankir syariah dapat menciptakan iklim investasi yang sehat dan adil, karena semua pihak dapat berpartisipasi dalam profit taking dan potensi risiko yang dapat memalukan. Ketiga, perbankan syariah membutuhkan dukungan vital berupa undang-undang yang secara khusus mengatur perkembangan lembaga-lembaga tersebut. ${ }^{8}$

\footnotetext{
${ }^{7}$ Depri Liber Sonata, 'Metode Penelitian Hukum Normatif Dan Empiris Karakteristik Khas Dari Metode Meneliti Hukum', Fiat Justisia Jurnal Ilmu Hukum, Volume 8. Nomor 1, 2014. hlm. 18.

${ }^{8}$ Zubairi Hasan, Undang-Undang Perbankan Syariah Titik Temu Hukum Islam Dan Hukum Nasional. Jakarta: PT Raja Grafido Persada, 2009. hlm. 81.
} 
Implikasi terpenting dari keberadaan dan perkembangan undang-undang ini bagi bank syariah adalah sebagai berikut: pertama, adanya jaminan kepastian hukum. Jaminan kepastian hukum merupakan hal yang fundamental dan penting bagi para pelaku usaha khususnya yang menggunakan jasa perbankan syariah. Demikian pula, kepastian hukum demikian ini akan turut membantu para investor, baik lokal maupun asing, untuk turut menanamkan investasinya ke dalam perbankan syariah. Kedua, peningkatan dukungan pemerintah. Lahirnya undang-undang ini tentu akan semakin meningkatkan dukungan pemerintah yang lebih nyata dalam memajukan perbankan syariah. Tingkat dukungan pemerintah tersebut dapat berupa peningkatan sosialisasi kepada masyarakat luas yang belum memiliki pengetahuan yang memadai menyangkut perbankan syariah. Selain itu, dukungan pemerintah dapat diwujudkan dalam mengundang investor, baik dari dalam maupun luar negeri, untuk mengembangkan industri perbankan di tanah air. ${ }^{9}$ Ketiga, terintegrasinya peran BI dan DPS. Sebagai undang-undang yang khusus mengatur perbankan syariah, undang-undang ini juga mengatur tentang masalah kepatuhan syariah yang kewenangannya berada pada MUI dan direpresentasikan oleh DPS pada masing-masing Bank syariah dan UUS, sebagaimana dijelaskan dalam penjelasan umum Penjelasan Umum UU Nomor 21 Tahun 2008 tentang Perbankan Syariah.

Mengenai pelaksanaan prinsip syariah dalam produk perbankan secara teknis diatur melalui Pasal 2 dan Pasal 3 PBI Nomor 9/19/PBI/2007 tentang Pelaksanaan Prinsip Syariah dalam Kegiatan Penghimpunan Dana dan Penyaluran Dana serta Pelayanan Jasa Bank Syariah, serta Surat Edaran Bank Indonesia Nomor 10/14/DPbS Jakarta perihal Pelaksanaan Prinsip Syariah dalam Kegiatan Penghimpunan Dana dan Penyaluran Dana serta Pelayanan Jasa Bank Syariah tertanggal 17 Maret 2008. Dalam rangka menyesuaikan diri dengan UU 21/2008, PBI Nomor 9/19/PBI/2007 dimaksud telah diubah dengan PBI Nomor 10/16/PBI/2008. Pada konteks ini maka peraturan tersebut di atas telah menjadi legalisasi kegiatan unit usaha syariah Bank Jateng, sehingga secara hukum maka kegiatan unit usaha syariah tersebut sudah sah secara hukum.

Pasal 2 PBI Nomor 10/16/PBI/2008 pada intinya menyatakan bahwa kegiatan usaha penghimpunan dana, penyaluran dana, dan pemberian jasa perbankan yang dilakukan oleh bank adalah jasa perbankan berdasarkan prinsip syariah. Pelaksanaan kegiatan tersebut harus sesuai dengan prinsip syariah, yaitu dengan memenuhi ketentuan terpenting dari hukum

${ }^{9}$ Rukmana Amir Machmud, Bank Syariah: Teori, Kebijakan Dan Studi Empiris Di Indonesia. Jakarata: Erlangga, 2010. hlm. 74 
Islam, antara lain prinsip keadilan dan keseimbangan ('adlwatawazun), kemanfaatan (maslahah) dan universalisme (alamiyah) serta tidak mengandung gharar. maysir, riba, kezaliman dan barang haram. Bagi umat Islam, belat tumit secara keseluruhan adalah haram, baik belat tumit ganda maupun belat tumit rendah, dan belat tumit adalah perbuatan yang memalukan karena merampok tetangganya. Tidak masalah apakah itu dilakukan oleh individu pribadi atau oleh gereja institusional di mana semuanya seperti bagi umat Islam di haram. Meskipun masih ada beberapa pendapat, khususnya di Indonesia yang masih meragukan bahwa suku bunga bank adalah riba, sebenarnya sudah menjadi kesepakatan antara ulama, ahli fiqh dan bankir syariah di seluruh dunia.. ${ }^{10}$

Kemudian Pasal 3 PBI Nomor 9/19/PBI/2007 menegaskan bahwa prinsip syariah sebagaimana dimaksud dalam Pasal 2 Ayat (1) dalam kegiatan penghimpunan dana, antara lain penggunaan akad Wadi'ah dan Mudharabah, kegiatan penyaluran dana dalam bentuk pembiayaan antara lain dengan menggunakan akad Mudharabah, Musyarakah, Murabahah, Salam, Istishna', Ijarah, Ijarah Muntahiya Bitamlik dan Qardh serta kegiatan jasa yang meliputi Kafalah, lah Kafalah Hawa dan akad.

Perbankan syariah di Indonesia saat ini sudah matang dan banyak faktor yang akan mempengaruhi percepatan perkembangan perbankan syariah di masa depan, salah satunya adalah faktor legalisme. Arah perkembangan perbankan syariah juga akan berpengaruh pada masa depan perkembangan infrastruktur hukum perbankan syariah di Indonesia. Oleh karena itu, langkah-langkah perbaikan dalam pengembangan sektor perbankan syariah telah melalui berbagai proses, terutama dalam peraturan dan pedoman pemerintah. Selain itu, menyusul berlakunya Peraturan Perbankan Syariah dan diperkuat dengan berlakunya Undang-Undang Nomor 21 Tahun 2008 tentang Perbankan Syariah. Namun penerbitan pasal tersebut tidak sepenuhnya berdampak positif dan perang kemaslahatan masyarakat, sebagaimana tercantum dalam Pasal 68 Undang-Undang Nomor 21 Tahun 2008:

"1. Dalam hal Bank Umum Konvensional memiliki UUS yang nilai asetnya telah mencapai paling sedikit 50\% (lima puluh persen) dari total nilai asset bank induknya atau 15 (lima belas) tahun sejak berlakunya Undang-undang ini, maka Bank Umum Konvensional dimaksud wajib melakukan Pemisahan UUS tersebut menjadi Bank Umum Syariah."

"2. Ketentuan lebih lanjut mengenai pemisahan dan sanksi bagi Bank Umum Konvensional yang tidak melakukan pemisahan sebagaimana dimaksud pada Ayat 1 diatur dengan Peraturan Bank Indonesia."

${ }^{10}$ Arief Budiono, 'Penerapan Prinsip Syariah Pada Lembaga Keuangan Syariah', Law and Justice Jurnal, Volume 2. Nomor 1, 2017. hlm. 58. 
Dalam pasal tesebut terkandung pengaturan kapitalisasi perbankan syariah. Pasal ini memberikan penjelasan bahwa Usaha Unit Syariah (UUS) yang sudah memiliki modal sebesar 50\% atau telah beroperasi selama 15 tahun sejak disahkannya UU ini maka diharuskan untuk melakukan pemisahan / spin off unit syariahnya. Sedangkan pengertian dari Spin Off menurut Pasal 1 angka 32 UUPS yaitu pemisahan (spin off) adalah pemisahan usaha dari satu bank menjadi dua badan usaha atau lebih, sesuai dengan ketentuan peraturan perundang undangan. Unit Usaha Syariah Bank Jateng masih berstatus Unit Usaha Syariah menunjukkan kinerja yang bagus dan membanggakan. Total asset per-31 Desember 2019 (YoY) tumbuh 11,67\%, Rp 5,736.732 T. Dana Pihak Ketiga (DPK) tumbuh 14,07\% Rp 2,722.371 T. Pembiayaan tumbuh 8,87\% menjadi Rp 3,010.215 T, dan laba usaha baru tercapai 91,70\%, direncanakan Rp 125 Milyar, sedikit turun menjadi Rp 114,621 Milyar.

Secara umum dapat dikatakan bahwa pertumbuhan UUS Bank Jateng tahun 2019 sangat bagus, baik Aset, Pembiayaan, dan Dana Pihak Ketiga, berada di atas pertumbuhan Perbankan dan Perbankan Syariah di Jawa Tengah (Laporan Div UUS, 2020). Kontribusi Unit Usaha Syariah Bank Jateng, Aset di angka 7,37\%, pembiayaan 5,79\%, DPK 5,23\%, dan laba usaha 7,65\%. Unit Usaha Syariah Bank Jateng, memiliki asset 19,96\%, DPK 11,97\%, dan pembiayaan sebesar 13,17\%. Dengan kantor cabang Syariah di 5 Kabupaten/Kota, 14 Kantor Cabang Pembantu Syariah, 5 kantor kas, meskipun berkinerja bagus dan membanggakan, namun masih banyak tantangan dan hambatan yang harus dijawab dengan kerja nyata oleh manajemen dan pimpinan UUS. Di antara yang prioritas adalah pengembangan produk dan jasa layanan UUS masih terkendala IT (Information Technology), pemenuhan SDM, kapasitas, dan produktifitas masih perlu ditingkatkan, belum terealisasinya penyesuaian SOTK sesuai kebutuhan bisnis UUS, dan belum optimalnya distribusi chanel melalui Kantor Layanan Syariah (KLS).

Undang Undang Nomor 21 Tahun 2008 selain memberikan hak bagi Bank Umum Konvensional untuk melepas atau memisahkan UUS yang dimiliki, pada ketentuan peralihan Pasal 68 justru mewajibkan Bank Umum Konvensional yang telah memenuhi persyaratan tertentu untuk melakukan pemisahan UUS. Selain itu juga dengan adanya pasal tersebut maka di tahun 2023 yang akan datang maka UUS diwajibkan untuk melakukan spin off apabila kegiatan tersebut tidak dilaksanakan maka akan mendapatkan sanksi sesuai peraturan yang telah dijalankan. Unit Usaha Syariah Bank Jateng masih ada PR yang harus dikerjakan, yaitu persiapan Spin Off Unit Usaha Syariah (UUS) dalam penerapan peraturan Pasal 68 UndangUndang Nomor 21 Tahun 2008 tentang Perbankan Syariah. 
Dalam kegiatan operasional selalu berpedoman pada ketentuan dan prinsip syariah, sebagaimana diatur dalam UU Nomor 21 Tahun 2008, Ketentuan dari Bank Indonesia dan Fatwa Dewan Syariah Nasional. Di samping hal tersebut, Bank Jateng juga memiliki Dewan Pengawas Syariah yang secara langsung mengawasi kegiatan Unit Usaha Syariah dengan beberapa tugasnya. Dewan Pengawas Syariah secara umum tugasnya yaitu bertanggungjawab terhadap pengawasan perbankan syariah. ${ }^{11}$

Tugas yang pertama yaitu menilai dan memastikan pemenuhan Prinsip Syariah atas pedoman operasional dan produk yang dikeluarkan bank. Tugas kedua yaitu mengawasi proses pengembangan produk baru bank agar sesuai dengan fatwa DSN-MUI. Tugas ketiga yaitu meminta fatwa kepada DSN-MUI untuk produk baru yang belum ada fatwanya. Tugas keempat yaitu memberikan opini syariah terhadap produk baru dan atau pembiayaan yang direstrukturisasi. Tugas kelima yaitu melakukan review secara berkala atas pemenuhan prinsip syariah terhadap mekanisme penghimpunan dana dan penyaluran dana serta pelayanan jasa bank. Tugas keenam dari Unit Usaha Syariah yaitu Meminta data dan informasi terkait dengan aspek syariah dari satuan kerja bank dalam rangka pelaksanaan tugasnya. Dalam penerbitan dan pelaksanaan ketentuan Dewan Pengawas Syariah selalu terlibat dengan memberikan rekomendasi terhadap ketentuan dan peraturan yang diterbitkan.

Eksistensi Unit Usaha Syariah Bank Jateng bila dilihat dari kinerjanya secara umum dapat dikatakan baik, hal ini bisa terlihat dari aspek Aset, Pembiayaan, dan Dana Pihak Ketiga, berada di atas pertumbuhan Perbankan dan Perbankan Syariah di Jawa Tengah. Namun demikian meskipun berkinerja bagus dan membanggakan, Eksistensi Unit Usaha Syariah Bank Jateng masih mengalami beberapa hambatan yang menjadikannya tidak eksis sehingga harus dilakukan beberapa evaluasi dan perbaikan oleh jajaran managementnya. Halhal yang harus menjadi evaluasi adalah terkait dengan pengembangan produk dan jasa layanan Unit Usaha Syariah Bank Jateng masih terkendala IT (Information Technology), pemenuhan SDM, kapasitas, dan produktifitas masih perlu ditingkatkan, belum terealisasinya penyesuaian SOTK sesuai kebutuhan bisnis UUS, dan belum optimalnya distribusi chanel melalui Kantor Layanan Syariah (KLS). Produk dan layanan Unit Usaha Syariah akan menjadi semakin inovatif jika Sumber Daya Manusia (SDM) di dalamnya juga berpikiran kreatif dan inovatif. Sehingga hal yang paling penting untuk dilakukan sekaligus menjadi hal

11 Bella Gita Novalia. Muzdalifa, Irma, Inayah Aulia Rahma, 'Peran Fintech Dalam Meningkatkan Keuangan Inklusif Pada UMKM Di Indonesia (Pendekatan Keuangan Syariah)', Jurnal Masharif Al-Syariah: Jurnal Ekonomi Dan Perbankan Syariah, Volume 3. Nomor 1, 2018. hlm. 16. 
yang harus dijadikan program kerja management di Bank Jateng adalah melakukan Upgrading SDM di Bank Jateng pada umumnya dan Unit Usaha Syariah pada khususnya. Upgrading adalah salah satu program kerja dan tanggungjawab pelaksanaannya di management dan dilakukan oleh bidang Sumber Daya Manusia (SDM) Unit Usaha Syariah yang bertujuan untuk meningkatkan kemampuan anggota Indikator yang mendukung kinerja organisasi.

\section{Strategi Unit Usaha Syariah PT. Bank Pembangunan Daerah Jawa Tengah Agar Semakin Eksis}

Berangkat dari permasalahan eksistensi Unit Usaha Syariah PT Bank Jateng di atas, pada bagian ini akan diuraikan mengenai strategi Unit Usaha Syariah PT Bank Jateng agar semakin eksis. Hal ini dapat dilakukan dengan outsourcing sebagai lembaga hukum baru di Indonesia yang diperkenalkan oleh Undang-Undang Nomor 40 Tahun 2007 tentang Perseroan Terbatas (UUPT) dan Undang-Undang 21 Tahun 2008 (UUPS). Dalam hukum perseroan, pemisahan diartikan sebagai suatu tindakan hukum yang dilakukan oleh suatu perusahaan untuk memisahkan usahanya dan yang mengakibatkan secara hukum beralihnya seluruh kekayaan dan kewajiban perusahaan kepada satu atau lebih perusahaan, atau secara hukum beralihnya sebagian kekayaan perusahaan dan kewajiban kepada satu atau lebih perusahaan. Dalam konteks bank, fasilitas pemisahan ini diartikan sebagai pemisahan kegiatan usaha bank menjadi dua atau lebih unit usaha sesuai dengan ketentuan peraturan perundang-undangan. ${ }^{12}$

Pasal 135 Ayat (1) UUPT mengatur bahwa pemisahan dapat dilakukan dengan pemisahan murni atau pemisahan tidak murni. Pemisahan bersih mengakibatkan seluruh aktiva dan pasiva Perseroan beralih karena hukum kepada 2 atau lebih Perseroan lain yang menerima pengalihan, dan Perseroan yang melakukan pemisahan tersebut berakhir demi hukum. Sementara itu, pemisahan sementara mengakibatkan sebagian harta dan kewajiban Perseroan beralih karena hukum kepada satu atau lebih perusahaan lain yang menerima pengalihan tersebut, dan perusahaan hasil pemisahan tersebut tetap ada.

Pengertian mengenai pemisahan (spin off) dapat ditemukan juga dalam Black's Law Dictionary, yaitu sebagai berikut:

${ }^{12}$ Parman Komarudin Muhammad Rifqi Hidayat, 'Penyelesaian Sengketa Wakaf Melalui Jalur Litigasi Dan Non-Litigasi', Al-Adl : Jurnal Hukum, Volume. 11. Nomor 2, 2019. hlm. 187. 
Spin-off is a corporate divestiture in which a division of a corporation be-comes on independent company and stock of the new company is distributed to the corporation's shareholders. ${ }^{13}$

Dalam hal ini unit usaha Syariah Bank Jateng, dapat menjadi Bank Umum Syariah tersendiri setelah mendapat persetujuan dari Bank Indonesia. Ketentuan ini, sebagaimana disebutkan di atas, menunjukkan bahwa bank umum, yang telah mendirikan UUS di kantor pusatnya dan secara sukarela memberikan layanan Syariah melalui mekanisme Islamic window, dapat memisahkan UUS yang meragukan dan menjadi Bank Umum Syariah, sebuah firma hukum yang independen. ${ }^{14}$

Perusahaan perbankan syariah dapat dibagi menjadi tiga kelompok, yaitu Bank Umum Syariah, Bank Pembiayaan Rakyat Syariah dan Unit Usaha Syariah. Secara singkat tiga bentuk perusahaan dari industri perbankan syariah. Bank Umum Syariah (BUS) adalah "bank syariah yang kegiatannya memberikan layanan untuk membiayai lalu lintas." Sebagai unit usaha, kegiatan usaha bank syariah pada dasarnya sama dengan bank tradisional, yaitu menyetorkan dan menyalurkannya kepada masyarakat untuk menghimpun dana dari masyarakat. Melaksanakan kegiatan keuangan dan kegiatan lainnya untuk masyarakat.

Kegiatan lain tersebut antara lain melakukan bakti sosial berupa penerimaan dan penyaluran dana zakat, infaq, sedekah dan dana zakat. Sebelum Undang-Undang Perbankan Syariah mulai berlaku, bank pembiayaan syariah dikenal sebagai Bank Perkreditan Rakyat Syariah. Istilah 'pembiayaan' digunakan sebagai pengganti 'kredit' karena tidak dikenal sebagai pinjaman berbunga dalam operasi bisnis bank syariah. BUS dan BPRS merupakan perantara keuangan, namun BPRS tidak diperkenankan memberikan jasa dalam lalu lintas pembayaran. Unit Usaha Syariah (UUS) adalah unit kerja dari kantor pusat bank umum tradisional yang bertindak sebagai kantor pusat atau unit kantor cabang yang melakukan kegiatan usaha berdasarkan prinsip syariah. Bank yang berkedudukan di luar negeri melakukan kegiatan usaha. Secara tradisional berfungsi sebagai kantor cabang pembantu Syariah dan / atau kantor utama unit Syariah. ${ }^{15}$

\footnotetext{
${ }^{13}$ Elizabeth A. and Jonathan Law Martin, Oxford Dictionary of Law, 5th edn. New York: Oxford University Press, 2006.p. 1443.

${ }^{14}$ Ade Yatshah Basuki, 'Analisis Yuridis Terhadap Konversi Bank Konvensional Menjadi Bank Syariah, Studi Pada PT Bank Aceh Syariah Kantor Utama Banda Aceh’ (Universitas Sumatera Utara, 2017).hlm. 3.

${ }^{15}$ Sinathrya Al Kautsar, 'Pengaruh Konversi Bank Konvensional Menjadi Bank Syariah Terhadap Risiko Kebangkrutan Studi Kasus Pada Bank Aceh', Jurnal Ekonomi Dan Bisnis Universitas Udayana, Volume 8. Nomor 1, 2014. hlm. 555.
} 
Peraturan Bank Indonesia sebagaimana dimaksud dalam Pasal 68 Ayat (2) UUPS adalah PBI No 11/10/PBI/2009 untuk Unit Usaha Syariah (PBI). Pasal 1 Ayat (14) PBI mendefinisikan pembagian sebagai pembagian dari BUK (Bank Umum Konvensionl) menjadi dua atau lebih entitas ekonomi sesuai dengan peraturan perundang-undangan yang berlaku pada waktu tertentu. Berdasarkan peraturan tersebut maka peraturan perundangundangan yang berlaku bagi Perseroan Terbatas berlaku sepanjang tidak diatur secara tegas dalam PBI ini. Pembagian dilaksanakan oleh Direksi, tetapi Rapat Umum Pemegang Saham (RUPS) memutuskan persetujuan pembagian. Direksi harus berkonsultasi dengan kreditur. Jika kreditur berkeberatan dengan rencana tersebut, rencana tersebut harus disampaikan kepada RUPS untuk diputuskan. Sampai kesepakatan tercapai, pembagian tidak dapat dilakukan. Ini untuk kepentingan kreditur karena pemilik perusahaan mungkin memiliki niat buruk menggunakan lembaga divisi ini sebagai celah untuk menghindari pembayaran hutang atau hutang. Pemisahan juga dapat menjadi jalan keluar apabila terjadi perselisihan antar pemegang saham sehingga masing-masing dapat memiliki perusahaan baru. ${ }^{16}$

Ketentuan teknis unbundling UUS diatur dalam PBI IX dari Bab 40 hingga 54 dan diatur oleh beberapa Pasal. PBI ini menegaskan ketentuan Pasal 68 UUPS, yaitu Bank Umum Konvensional (BUK) pemilik UUS wajib memilih UUS kepada BUS apabila: (i) nilai aset UUS telah mencapai 50\% ( lima puluh persen) dari total nilai kekayaan BUK. atau (ii) paling lambat 15 (lima belas) tahun sejak berlakunya Undang-Undang Nomor 21 Tahun 2008 tentang Perbankan Syariah. Pasal 45 PBI 11/10/PBI/2009 menyebutkan bahwa modal disetor bank umum syariah hasil pemekaran paling sedikit Rp 500 miliar. Modal tersebut kemudian akan ditingkatkan secara bertahap menjadi minimal $\mathrm{Rp} 1$ triliun dan akan dilunasi paling lambat 10 tahun setelah Bank Indonesia memberikan izin kepada Bank Umum Syariah.

Saat ini, berdasarkan Pasal 4 PBI, modal kerja Unit Usaha Syariah minimal Rp 100 miliar dan harus disisihkan dalam bentuk tunai. Apabila Bank Umum Konvensional tidak melaksanakan pemisahan yang diperintahkan oleh Bank Indonesia, maka izin usaha yang dimiliki UUS dicabut. Bukan tidak mungkin bank memenuhi jangka waktu 15 tahun untuk divestasi UUS dan penambahan modalnya. Namun, dampak krisis keuangan global tampaknya masih akan mempengaruhi beberapa sektor di tanah air, termasuk sektor perbankan.

${ }^{16}$ Verina Yuwono Setianto, 'Pertanggungjawaban Pribadi Direksipada Perseroan Terbatas Yang Pailit'. Universitas Airlangga, 2017. hlm. 51. 
Tentu kondisi ini bukan hal yang mudah untuk Bank Umum Konvensional. Untuk menambah modal sendiri saja mereka perlu merangkak, apalagi harus menambah modal di Unit Usaha Syariah-nya. Dapat ditegaskan bahwa PBI ini menjadi beban baru bagi Bank Umum Konvensional yang memiliki UUS, khususnya Bank Umum Konvensional yang mempunyai aset tidak begitu besar. Namun demikian, Bank Indonesia tetap memberi opsi kepada Bank Umum Konvensional. Ada dua cara yang dimungkinkan, yakni pertama, mendirikan Bank Umum Syariah yang baru; kedua, mengalihkan hak dan kewajiban UUS kepada Bank Umum Syariah (BUS) yang telah ada. Hal lain yang juga perlu menjadi perhatian dari Bank Umum Konvensional yang hendak melepaskan UUS-nya, yaitu pengalihan hak dan kewajiban UUS dan kesiapan pendanaan, serta ketersediaan dana; rencana terhadap manajemen dan pegawai UUS; penyelesaian hak dan kewajiban terhadap pihak ketiga.

Demikian secara singkat mengenai mekanisme pemisahan UUS dari bank konvensional selaku induk. PT. BRI Syariah yang merupakan anak perusahaan PT. Bank Rakyat Indonesia (Persero) Tbk. adalah contoh sukses dari pemisahan (spin off) yang tujuannya adalah untuk meningkatkan efektivitas dan efisiensi kegiatan usaha, serta ketaatan terhadap prinsip syariah. Bagaimana strategi UUS Bank Jateng dalam Penerapan UndangUndang Nomor 21 Tahun 2008 adalah sebagai berikut; Memberikan kontribusi yang signifikan terhadap perolehan laba Bank Jateng, mengandung arti bahwa keberadaan Unit Usaha Syariah Bank Jateng yang merupakan perluasan dari pelayanan jasa keuangan Bank Jateng diharapkan mampu memberikan kontribusi terhadap perolehan laba Bank. Produk jasa UUS Bank Jateng yang didasarkan pada Undang-Undang Nomor 21 Tahun 2008, hal ini akan menjadi penguat dan menimbulkan kepercayaan masyarakat Indonesia yang merupakan nilai utama dari suatu bisnis. Sehingga strategi penguatan jasa UUS Bank Jateng tersebut adalah hal yang penting untuk dilakukan.

Menyediakan produk-produk dan jasa perbankan syariah dengan layanan prima untuk memberikan kepuasan dan nilai tambah bagi nasabah dan masyarakat sehingga mampu menggerakkan sektor riil sebagai pilar pertumbuhan ekonomi regional. Artinya dengan slogan Perbankan Syariah "Beyond Banking" yaitu Bukan Sekedar Bank, maka Unit Usaha Syariah Bank Jateng diharapkan mampu untuk mengembangkan berbagai variasi produk dan layanan sehingga dapat menampung kebutuhan masyarakat akan jasa keuangan perbankan syariah. Menggerakkan sektor riil yaitu Unit Usaha Syariah Bank Jateng diharapkan mampu berperan 
aktif mendorong pengembangan ekonomi daerah, dengan mengutamakan pembiayaan disektor usaha kecil menengah sehingga dapat meningkatkan taraf hidup masyarakat.

Menjalin kemitraan dengan pihak-pihak terkait untuk membangun sinergi dalam pengembangan bisnis, artinya terus menerus meningkatkan komunikasi dan kerjasama dengan pihak-pihak terkait baik dengan instansi Pemerintah maupun swasta dalam rangka membangun dan mengembangkan bisnis bank. Memberikan peluang dan dorongan bagi seluruh karyawan dengan mengembangkan seluruh potensi dirinya untuk kesejahteraan diri dan keluarganya, nasabah serta masyarakat pada umumnya artinya keberadaan Unit Usaha Syariah Bank Jateng memberikan peluang kepada seluruh karyawan untuk pengembangan potensi diri dan karier sehingga akan berdampak positif terhadap kesejahteraan diri dan keluarga serta masyarakat disekitarnya.

Dalam mewujudkan Visi dan Misi Unit Usaha Syariah Bank Jateng, pelaksanaannya mendasar kepada arah kebijakan Unit Usaha Syariah Bank Jateng Jangka Menengah, yaitu penguatan struktur organisasi dan pengembangan Bisnis Model sehingga mampu memberikan kepuasan nasabah dengan diversifikasi produk dan layanan yang didukung dengan sistem dan teknologi informasi yang handal sehingga mampu memberikan kontribusi yang signifikan terhadap perkembangan Bank Jateng. Disamping itu juga tetap fokus pada penguatan bisnis UUS yang sehat. Sedangkan dalam jangka pendek (2021), Kebijakan UUS Bank Jateng diarahkan pada persiapan menuju Spin Off dengan memperkuat di sisi permodalan, memperkuat bisnis dan kelembagaan Unit Usaha Syariah melalui pengembangan layanan, jaringan, Sumber Daya Insani (SDI) dan Teknologi Informasi, peningkatan modal untuk meningkatkan pertumbuhan usaha dan market share dengan berorientasi pada pengendalian risiko. Di samping itu juga memfokuskan penguatan bisnis UUS yang sehat dan kuat dalam rangka persiapan Spin Off Unit Usaha Syariah.

Memperkuat operasional dilakukan dengan melakukan pengembangan strategi model bisnis yang menggambarkan pemikiran tentang bagaimana sebuah organisasi secara agresif menciptakan, memberikan, dan menangkap nilai-nilai baik itu ekonomi, sosial, ataupun bentuk-bentuk nilai lainnya. Perluasan operasional melalui strategi penetrasi pasar adalah dengan meningkatkan layanan serta terus menerus melakukan edukasi dan sosialisasi tentang produk-produk Unit Usaha Syariah Bank Jateng kepada masyarakat. ${ }^{17}$

${ }^{17}$ Ade Sofyan Mulazid, 'Pelaksanaan Sharia Compliance Pada Bank Syariah (Studi Kasus Pada Bank Syariah Mandiri, Jakarta)', Madani, Volume 20. Nomor 1, 2016. hlm. 39. 
Untuk mendukung perluasan operasional Unit Usaha Syariah Bank Jateng akan dilakukan perluasan jaringan operasional Bank. Pada tahun 2021, Unit Usaha Syariah Bank Jateng merencanakan pembukaan jaringan kantor berupa Kantor Cabang Pembantu Syariah (KCPS). Oleh karena itu perlu dilakukan penambahan tenaga kerja atau SDI dengan merekrut tenaga fresh graduate maupun dengan melakukan pro hire tenaga kerja/SDI yang sudah berpengalaman, terutama berpengalaman di bisnis syariah dan teknologi informasi.

Upaya memperkuat kualitas Sumber Daya Insani dilakukan melalui kegiatan pelatihan yang dilakukan baik secara in-house maupun ex-house trainning. Hal tersebut dimaksudkan untuk meningkatkan kualitas Sumber Daya Insani khususnya di lingkungan Unit Usaha Syariah Bank Jateng sehingga mampu membawa Unit Usaha Syariah Bank Jateng sebagai Bank Syariah yang berkualitas, handal dan memiliki daya saing serta mampu membentuk brand image yang baik terhadap keberadaan Unit Usaha Syariah Bank Jateng di masyarakat. Penguatan di bidang Teknologi Informasi dibutuhkan untuk meningkatkan daya saing produk dan layanan dalam rangka memberikan pelayanan sesuai kebutuhan nasabah. Memperkuat permodalan dari Bank Jateng yang disesuaikan dengan perkembangan kinerja Unit Usaha Syariah dalam rangka memperkuat Bank menuju Spin Off. Penambahan modal tersebut sebagai penunjang pertumbuhan usaha dan penguasaan pasar dengan selalu melakukan pemantauan dan pengendalian terhadap kemungkinan munculnya risiko.

Sesuai dengan arah kebijakan tersebut, maka dirumuskan langkah-langkah strategis untuk menjadikan Unit Usaha Syariah Bank Jateng semakin eksis sebagai berikut; Pertama menentukan segmentasi pasar unggulan yang menjadi fokus bisnis. Kedua yaitu pengembangan produk dan layanan baik dari variasi, kelengkapan produk, maupun fitur sesuai dengan kebutuhan nasabah. Ketiga, integrasi dan bersinergi dengan perusahaan penunjang bisnis, Keempat yaitu revitalisasi ketentuan internal terkait dengan dinamika bisnis (bisnis model dan bisnis proses). Kelima, Revitalisasi di bidang SDI sebagai penggerak pertumbuhan bisnis dan Penguatan Corporate Culture. Keenam, Integrasi jasa layanan dan memaksimalkan Layanan Syariah pada jaringan Bank Jateng, dan strategi terakhir yaitu memperkuat bisnis untuk mencapai skala ekonomis dalam rangka persiapan menuju Spin Off menjadi Bank Umum Syariah yang sehat dan kuat.

\section{PENUTUP}

Berdasarkan hasil pembahasan dalam penelitian bisa dikemukakan bahwa; 
Eksistensi Unit Usaha Syariah Bank Jateng bila dilihat dari kinerjanya secara umum dapat dikatakan baik, hal ini bisa terlihat dari aspek Aset, Pembiayaan dan Dana Pihak Ketiga, berada di atas pertumbuhan Perbankan dan Perbankan Syariah di Jawa Tengah. Namun demikian meskipun berkinerja bagus dan membanggakan, Eksistensi Unit Usaha Syariah Bank Jateng masih mengalami beberapa hambatan yang menjadikannya tidak eksis sehingga harus dilakukan beberapa evaluasi dan perbaikan oleh jajaran managementnya. Hal-hal yang harus menjadi evaluasi adalah terkait dengan pengembangan produk dan jasa layanan Unit Usaha Syariah Bank Jateng masih terkendala IT (Information Technology), pemenuhan SDM, kapasitas dan produktifitas masih perlu ditingkatkan, belum terealisasinya penyesuaian SOTK sesuai kebutuhan bisnis UUS, dan belum optimalnya distribusi channel melalui Kantor Layanan Syariah (KLS).

Langkah-langkah strategis untuk menjadikan Unit Usaha Syariah Bank Jateng semakin eksis sebagai berikut; Pertama menentukan segmentasi pasar unggulan yang menjadi fokus bisnis. Kedua yaitu pengembangan produk dan layanan baik dari variasi, kelengkapan produk, maupun fitur sesuai dengan kebutuhan nasabah. Ketiga, integrasi dan bersinergi dengan perusahaan penunjang bisnis, Keempat yaitu revitalisasi ketentuan internal terkait dengan dinamika bisnis (bisnis model dan bisnis proses). Kelima, Revitalisasi di bidang SDI sebagai penggerak pertumbuhan bisnis dan Penguatan Corporate Culture. Keenam, Integrasi jasa layanan dan memaksimalkan Layanan Syariah pada jaringan Bank Jateng, dan strategi terakhir yaitu memperkuat bisnis untuk mencapai skala ekonomis dalam rangka persiapan menuju Spin Off menjadi Bank Umum Syariah yang sehat dan kuat. 


\section{DAFTAR PUSTAKA}

\section{Buku}

Ade Yatshah Basuki, (2017), Analisis Yuridis Terhadap Konversi Bank Konvensional Menjadi Bank Syariah, Studi Pada PT Bank Aceh Syariah Kantor Utama Banda Aceh, Universitas Sumatera Utara.

Amir Machmud, Rukmana, (2010), Bank Syariah: Teori, Kebijakan Dan Studi Empiris Di Indonesia. Jakarata: Erlangga.

Antonio, Muhammad Syafiei, (2017), Bank Syariah: Dari Teori Ke Praktik. Jakarta: Gema Insani Press.

Martin, Elizabeth A. and Jonathan Law, (2006), Oxford Dictionary of Law, 5th edn, New York: Oxford University Press.

Setianto, Verina Yuwono, (2017), Pertanggungjawaban Pribadi Direksipada Perseroan Terbatas Yang Pailit, Universitas Airlangga.

Usman, Rachmadi, (2012), Aspek Hukum Perbankan Syariah Di Indonesia, Jakarata: Sinar Grafika.

Zubairi Hasan, (2009), Undang-Undang Perbankan Syariah Titik Temu Hukum Islam Dan Hukum Nasional, Jakarta: PT Raja Grafido Persada.

\section{Peraturan Perundang-Undangan}

Undang-Undang Dasar Negara Republik Indonesia Tahun 1945.

Undang-Undang Nomor 7 Tahun 1992 tentang Perbankan

Undang-Undang Nomor 10 Tahun 1998 tentang Perbankan.

Undang-Undang Nomor 40 Tahun 2007 tentang Perseroan Terbatas

Undang-Undang Nomor 21 Tahun 2008 tentang Perbankan Syariah.

\section{Jurnal}

Ade Sofyan Mulazid, (2016), "Pelaksanaan Sharia Compliance Pada Bank Syariah (Studi Kasus Pada Bank Syariah Mandiri, Jakarta)”, Madani, Volume 20. Nomor 1.

Arief Budiono, (2017), "Penerapan Prinsip Syariah Pada Lembaga Keuangan Syariah”, Law and Justice Jurnal, Volume 2. Nomor 1. 
Bella Gita Novalia. Muzdalifa, Irma, Inayah Aulia Rahma, (2018), "Peran Fintech Dalam Meningkatkan Keuangan Inklusif Pada UMKM Di Indonesia (Pendekatan Keuangan Syariah)", Jurnal Masharif Al-Syariah: Jurnal Ekonomi Dan Perbankan Syariah, Volume 3. Nomor 1.

Depri Liber Sonata, (2014), "Metode Penelitian Hukum Normatif Dan Empiris Karakteristik Khas Dari Metode Meneliti Hukum”, Fiat Justisia Jurnal Ilmu Hukum, Volume 8. Nomor 1.

Hafas Furqani dan Muhammad Adnan Syamsul Idul Adha, (2020), "Konversi Bank Konvensional Menjadi Bank Syariah Di Indonesia", Journal of Sharia Economics, Volume 1. Nomor 1.

Maulana Hamzah, (2009), "Optimalisasi Peran Dual Banking System Melalui Fungsi Strategis JUB Dalam Rangka Menjaga Stabilitas Sistem Keuangan Di Indonesia”, La_Riba Jurnal Ekonomi Islam, Volume 3. Nomor 2, 2009.

Parman Komarudin Muhammad Rifqi Hidayat, (2019), "Penyelesaian Sengketa Wakaf Melalui Jalur Litigasi Dan Non-Litigasi”, Al-Adl : Jurnal Hukum, Volume. 11. Nomor 2.

Prima Intan Sari, (2018), "Konversi Bank Konvensional Menjadi Bank Syariah Ditinjau Dari Hukum Positif Dan Hukum Islam”, At-Tasyri, Volume 11. Nomor 2.

Rof'ah Setyowati, (2017), "Rasionalitas Pendekatan Sharia Compliance Dalam Meningkatkan Kepercayaan Nasabah Perbankan Syariah", Jurnal Hukum Ekonomi Islam, Volume 1. Nomor 1.

Sinathrya Al Kautsar, (2014), "Pengaruh Konversi Bank Konvensional Menjadi Bank Syariah Terhadap Risiko Kebangkrutan Studi Kasus Pada Bank Aceh”, Jurnal Ekonomi Dan Bisnis Universitas Udayana, Volume 8. Nomor 1. 